\title{
The Performance of July 2013 NLE takers in Relation to Personality-based Psycho-Emotion Interventions
}

\author{
BONNIBELLA L. JAMORA \\ http://orcid.org/0000-0001-8864-6890 \\ jbonnibell_72@yahoo.com \\ IAM ALASTAIRE P. PALGAN \\ http://orcid.org/0000-0001-5595-3616 \\ iamalastaire_palgan@yahoo.com \\ APOLONIO G. BALILING \\ http://orcid.org/0000-0002-0475-6804 \\ apolonio.baliling@yahoo.com \\ LOVERN J. CLEMEÑA \\ http://orcid.org/0000-0001-8569-3798 \\ lovern.c@yahoo.com \\ LOURDES MARIE C. LAPEZ \\ http://orcid.org/0000-0002-2422-7379 \\ el4834@yahoo.com \\ RHODA MAE A. SIOCO \\ http://orcid.org/0000-0003-1247-1996 \\ sioco_rhodamay25@yahoo.com
}

\section{ABSTRACT}

The Nurse Licensure Examination (NLE) is the process of regulating the practice of nursing in the Philippines. Students who graduate from the nursing course need to take the NLE to practice the nursing profession. This study aimed to look into the performance of 
University of Bohol College of Nursing - July 2013 NLE-Takers in relation to the psycho-emotional intervention as a possible contributing factor on a personality-based approach. An interrupted time-series quasi-experimental research design was used in the study. A total of 89 graduates from the University of Bohol College of Nursing who enrolled at Powerhouse Training and Review Center and took the Nursing board examinations were included in the study. Four groups were purposely created according to the subject's personality type utilizing Hartman's Personality Profile aided by a standardized tool developed from a previous study. Performance of the subjects was measured through three (3) Time Series, namely: Pre-board 1, Pre-board 2 and NLE. Results showed that there was a significant relationship between personality-based psycho-emotional interventions and overall performance of the subjects according to their personality. A significant difference was obtained when one exam (pre-board 2) received psycho-emotional intervention while the other (pre-board 1) did not. Findings were also consistent that when both exams (pre-board 2 and NLE) received psycho-emotional interventions, there was a slight difference but were not related to 12 the intervention done according to personality.

Keywords: Nursing, quasi-experimental, chi-square test for independence, Nursing Licensure Examination, Psycho-emotional intervention, Personality, Philippines, Asia

\section{INTRODUCTION}

The nursing profession has been a very trending course ever since the advent of modern medical healthcare. The demand for the nursing profession remains high as long as the imbalance in the number of individuals who need nursing care and the supply of nurses continue to exist. As people get married and get pregnant, changes in the body may occur which needs the constant care and assessment of a health care provider. The babies that will soon be delivered need more care and nurturing as they have the highest tendency to get sick. Even adults get sick more often, more so with the older generation where a majority of them will be suffering from chronic ailment. It has then been a reality that people from all walks of life, from conception to the delivery of a newborn baby, to infancy, to adolescent, to adulthood, to the elderly until death; they all need the expertise of a nurse.

In Europe, it was observed that there were only a few number of nurses who have been actively working and it is composed predominantly of the younger generation (Tackenberg \& Müller, 2003). Such general composition 
of nurses in Europe has been associated to the fact that a lot of middle-aged nurses decided to leave their profession at an early age in response to occupational stress where the workload is very high with an unfavorable working environment (Coomber \& Barriball, 2007). Canada, on the other hand, is also projecting a significant shortfall of over 100,000 registered nurses (RNs) by 2016 (Canadian Nurses Association, 2002). The projected shortage has been due to some health care policy issues of the nation that fails to take into account the adequacy of a nursing workforce in Canada (Little, 2007). Moreover, the decreasing number of nurses has also been felt in other places such as the United States where it was noted that the delivery of a quality nursing care was already affected (Buerhaus, Donelan, Norman, \& Dittus, 2005).

The nursing profession is said to be a calling for someone who is ready to take the pains of taking care of the sick. Those who half-heartedly love their work as a nurse are often those who are easily dissatisfied and are burnt out. People often change their perception about anything. Even students who enrolled in the nursing course often value and have a positive perception about the nursing profession during their early college life but such perception often change especially when they are already exposed to the real-life situation of a professional nurse (Sand-Jecklin \& Schaffer, 2006).

The increasing workload and occupational stress (Duquette, Kérouac, Sandhu, Ducharme, \& Saulnier, 1995), as well as the nonsupportive work environment, are just some of the occupational stressors that cause burnout (McAbee, 1991). These are believed to be the factors that cause fast turnover among nurses in a foreign land (Jourdain \& Chênevert, 2010). The decreasing supply of nurses resulted in a more stressful work condition making them leave their profession prematurely at an early age (Tackenberg \& Müller, 2003. The nurse's professional commitment has been questioned then because it has been proven then in a study that the more satisfied the employees are and the more committed they are with their profession, the lesser tendency for them to leave the organization of which they worked (Lu, Lin, Wu, Hsieh, \& Chang, 2002). Plenty of research studies have been undertaken to give a better solution to the problem at hand. An in-depth investigation into the cause of such shortage has been instituted, and it all boils down to factors related to the nurses' dissatisfaction with their job. Such job dissatisfaction is brought about by some racial discrimination and harassment coming from their colleagues and even from the patients (Shields \& Price, 2007). 
There were different actions done by the different leaders of the countries affected by the shortage. They made changes in the working policies to lighten the nurse's workload thereby increasing their level of professional commitment (Nogueras, 2005). Aside from that, they started recruiting and bringing over nurses from overseas. Some of the affected countries even started offering immigrant status for nurses and their families just to make the recruitment process more enticing to international workers. Such measures were found out to be effective in attracting migrant nurses to work in Canada, Europe, and even the US. It was worthy to note that Filipinos comprised the majority of migrant nurses to the U.S compared to other internationals. However, the migration of Filipino nurses to foreign lands has also affected the health care system of the Philippines depriving the Filipinos of the quality health care services supposed to be provided to them by their own countrymen (Brush, Sochalski, \& Berger, 2004). The countries who had been hiring overseas nurses had also realized that their economies were also being affected as they were paying for the services of international nurses. Such realization prompted the US government to look into strategies that would minimize the hiring of international nurses in favor of their own. The federal state then enacted policies that curbed the migration of Filipinos and other international nurses in the U.S (Masselink \& Jones, 2014). All these greatly affected the working opportunities of Filipino nurses abroad for the past 5-10 years which also downsized the enrollment of the different colleges of nursing nationwide. However, due to the aging population of nurses in the U.S and the increasing growth of the elderly population in the country, there is still a looming projection on the shortage of nurses by the year 2020 (Iken, 2007).

At present, some adolescents have still decided to enroll in the nursing course with the hope of becoming a full-fledged nurse someday after successfully passing the Nursing Licensure Examination (NLE) where the basic nursing level competency of the examinees which considers the objectives of the nursing curriculum will be tested. The NLE has been a high-stakes exam for students, faculty, and school administrators and failure to pass the said examination often has financial as well as emotional consequences on the student (Lauchner, Newman, \& Britt, 2005).

Because of the value attributed to the success of the nurse licensure exam, it is important for the graduate to be properly prepared before hurdling the NLE. Exposure to enhanced remediation has been found out to be associated with improved odds of first attempt success especially 
when taking licensure examinations (Horton, Polek, \& Hardie, 2012). Review centers exist nationwide to help guide nursing graduates in tackling the NLE. The 2013 graduates of the University of Bohol - College of Nursing had chosen Powerhouse Training and Review Center to assist them in this endeavor. One of the packages offered by the said Review Center was the provision of a personality-based psycho-emotional intervention to their reviewees.

Taking the board examination is a major stressor that students should face after graduation. A stressor is any agent that produces stress at any time (Weissmann, 2007). Different individuals respond differently to the same stressor. The response would always depend on his genetic predisposition, age, social influences and environmental factors (Selye, 1956). Hans Selye emphasized that any situation that causes stress endangers life unless adequate adaptive responses are being instituted. A stressor must be properly addressed before it disrupts an individual's immune function. A person who is under stressful situation may either have the "fight or the flight response." Individuals who are about to take an academic examination are about to face a brief naturalistic stressor which causes some behavioral changes which are adaptive in nature (Segerstrom \& Miller, 2004). Human beings react to any stressful situation either physically or behaviorally. Females are more inclined to have a physical affiliation with the same sex or their loved ones compared to males. They are more at ease when they can release their worries to others and even become more comfortable when they received strong social support coming from their friends and loved ones (Taylor, Klein, Lewis, Gruenewald, Gurung, \& Updegraff, 2000).

Individuals who are under stress need to do something to maintain homeostasis and for him to go on with his normal life. According to the Psycho-emotional theory, individuals are motivated to participate in activities that aid to meet the dynamic needs elicited by both internal and external factors. It deals with the creative use of recreation to restore a sound mind. However, the type of activity that must be undertaken should have a high anticipated leisure benefit to the students to ensure high participation from them (Lehto, Park, Fu, \& Lee, 2014). It is also important that students feel that they are part of the group because failure to do so would greatly affect their academic performance (Gay, 2010). Stressed out individuals, therefore, have to engage in activities that would satisfy their psycho-emotional needs to promote growth, belongingness, self-actualization, and adaptation. 
Nursing graduates who are about to take the board examination need to adapt to the stressful situation that they are in to. Sister Callista Roy in her "Adaptation Model" focuses on the individual as a bio-psychosocial adaptive system. This model emphasizes that every human being is equipped with the capacity to cope up holistically with every stressor encountered. However, the type of adaptive behavior that a person undertakes would always depend on his desire to maintain integrity and transformation (Freeman \& Morgillo, 2005). Roy identifies four different modes of adaptation which includes the physiologic-Physical mode; Self-conceptGroup Identity Mode; the Role function Mode; and the Interdependence Mode (Alligood, 2013). The physiologic adaptive mode refers to the way the individual interacts with his environment, how the individual responds physiologically to stress; the self-concept mode refers to how the person sees himself as an individual which includes his self-ideal and his moralethical-spiritual self. The role function mode of the individual refers to the different roles that the individual engaged in the society; while the interdependence mode points to the individual's interaction with other human beings. This mode has something to do with the giving and receiving of love, respect and value (Parker \& Smith, 2010). Roy further emphasizes that each human being has the innate and acquired capacity to cope with stress. An adaptive mechanism in response to stress may occur as bodily processes functions to cope with and adapt to the presence of the stressor. Furthermore, the individual is also equipped with knowledge, perception, and life experiences which he/ she can use together with the application of the correct judgment and using the right emotion in response to any given stressor (Phillips, Blue, Brubaker, Fine, Kirsch, Papazian, \& Sobiech, 1998).

Several research studies have been developed anchored on Roy's Adaptation model as they relate to psycho-emotional coping and anxiety. One of the best techniques that should be performed to help reduce examination stress is to believe in oneself as it is one of the greatest factors to success (Peale, 2012). Laughter may not be the best medicine for an anxious individual, but it has a positive effect on stress (Agarwal, 2014). It moderates the impact of stressful life event (Penson, Partridge, Rudd, Seiden, Nelson, Chabner, \& Lynch, 2005) and it is good for the human body both physically and mentally (Mahony, 2000). Mirthful laughter promotes relaxation not only to those who are facing serious health problems but also to those who experience high level of anxiety (Bennett, Zeller, Rosenberg, \& McCann, 2003) as felt by students who are about to take the board examination. 
Engaging the individual in some activities that would divert their attention to the coming board examination is also very important as it refreshes their mind making it more capable for comprehension and analysis. However, these diversional activities are still not enough to reduce examination stress. To give them greater confidence when taking the NLE, they should be well-prepared both physically and psychologically. A thorough cognitive preparation that is combined with relaxation is very effective in reducing the examination anxiety of the student (Gregor, 2005). If intelligence level of the individual is average or above average, relaxation then plays a role in facilitating the coping reaction. Sharma (2011), in her study about "Stress and Relaxation in relation to personality" revealed that extroverts relax easily than introverts. In designing techniques of stress management, it is therefore important to take into consideration the personality and intelligence level of the individual. Though personality traits are stable, people can change their pattern of behavior as a result of therapy or intervention program (Pervin \& John, 1999).

Different individuals have distinctive personalities with differing qualities (Mischel et al., 2005). As said by most theorists on personality, no two human beings have the same characteristics. Humans are unique in their own way. They differ in their appearance, in the way they talk and even in the way they respond to stress. Freud's personality theory emphasized the therapies of the mind which are said to be effective when it is correlated with the person's personality. Graduates who are about to take the NLE are facing a major stressor in their life. To help ease the burden that these graduates are facing, some interventions are needed to be instituted to help them relax physically and emotionally based on their personality type.

The Hartman Personality Profile, created by Taylor Hartman divided personalities into four colors: Red (power wielders) and yellow (fun lovers) as the extroverts, while white (peacekeepers) and blue (good-doers) as the introverts. Extroverts love to mingle with the world while introverts love to be by themselves (Moore, Gardner, \& Guenthner, 2008). Academically, introverts are more inclined to perform well (ChamorroPremuzic, \& Furnham, 2003). Accordingly, personalities could be red, blue, White and Yellow. Reds are hungry for power; want to be productive; want to look good to others; should not be taken seriously, and seek leadership opportunities. Blues are motivated by altruism; seek intimacy; craved for being understood; need to be remembered and appreciated, and are directed by a strong strong moral conscience. Whites are 
motivated by peace; need kindness; prefer quiet strength; like to keep a low profile; are independent, and are motivated by other people's desire. The yellow one's value play; welcome praise; need emotional connections; want to be popular; and like action (Hartman, 2007).

The utilization of the different personality types according to Hartman is very useful especially in the identification and building of a strong interpersonal relationship from among the group of reviewees. The building of good interpersonal skill should be cultivated early to adolescents as most employers are looking into the emotional quotient of applicants nowadays and more apt to hire those applicants who possess good interpersonal skills (Moore et al., 2008). There are a lot of big corporations and organizations worldwide that made use of Hartman's Color Code Personality Profile in building a stronger interpersonal relationship from among their employees. The effective use of the personality color code is found out to be effective in carrying out team projects of any company.

\section{METHODOLOGY}

The researcher used an interrupted time-series quasiexperimental research design. Data in the study were collected longitudinally. All the subjects of the study went through interventions given equal opportunities. A Standardized research tool, the Hartman's Personality Profile was utilized.

The subjects of the study were 89 July 2013 NLE examinees from the University of Bohol which is an affiliate of Powerhouse Training and Review Center. All the subjects were reviewees of the same review center from the enhancement program held from the start of level 4 nursing until the actual board examination.

The researcher sent a letter to the review center requesting permission to conduct a study and along with technical assistance during the entire duration of the research activity and data gathering. Psycho-emotional intervention was introduced to the subjects in between data gathering to note the significant difference between pre and post intervention phase. Data were gathered objectively through their obtained scores.

The subjects were given simulated examination called Pre-board 1. The subjects were made to answer a 500 items multiple-choice question given by the review center applying a test-bank technique which is the 
same as in the actual board exam. The pre-board questions were taken from the previous Nurses Licensure Examinations. The subjects were asked to wear their prescribed school uniform just like that in the actual board examination. They simultaneously took the pre-board on classrooms with the same ventilation to actual testing sites with a proctor. The examination sheets utilized were also in the form of shading on an exclusively produced paper that would be fed on a Scantron Optical Scanner for computerized checking.

All conditions in the actual board examination were simulated. Simulation of nursing education is believed to increase students' confidence, knowledge and decreases their anxiety (Skrable \& Fitzsimons, 2014). The exit examination for nurses that is monitored is highly predictive determinants of students taking the licensure examination (Lauchner et al., 2005). When the results of the Pre-Board 1 were available, obtained scores were taken with permission for research purposes only.

After a month of continuous review, the subjects were then categorized according to their personalities utilizing Hartman's personality profile that divided the subjects into four distinct personalities of different orientation and interests. Fun-oriented personalities composed the yellow group, peacekeeper personalities made up the white group, good doers were the blue group and leadership oriented personalities were the red group.

When the grouping of the subjects was finalized, simultaneous psychoemotional interventions were done in parallel to their personality interests. Since the yellow personality value play and are motivated to have fun, the Yellow group held a sports fest. The white group which was motivated by peace, celebrated holy mass and different forms of prayers. The blue group went to the city jail and interacted in an outreach activity with prisoners since their personality type are directed by a strong, moral conscience. The red group members who sought leadership opportunities served as the planners of all the activities of the three different groups. Ceremonial stress debriefing activity was also organized by the review center which is being participated by all groups at the same time, same venue and having the same activity.

The following day, the subjects took the Pre-Board 2 with a different set of questions from other previous Nurse Licensure Examinations. Everything that is done on Pre-board 1 was also identically done on the Pre-board 2. When the results were available, the scores obtained were also recorded. 


\section{RESULTS AND DISCUSSION}

\section{Profile of the subjects}

Majority of the subjects from varying personalities were females between the ages of 21-22 years old. The result showed that nursing profession is being dominated by the female sex however such gender differences do not affect their performance in the clinical area (Chan, Chan, Lui, Yu, Law, Cheung, \& Lam 2014). The subjects had different personality types as identified by Hartman in his personality profile. The different colorcoded personality profile shows different traits and character (Hartman, 2000). As shown in Fig. 1, forty nine (55\%) of the subjects belonged to the Yellow group who loved to play, wanted to be popular, liked action and needed to be emotionally connected. Second from the biggest was the Blue group (19\%), composed of 17 persons who were the good doers who sought intimacy and needed to be understood, and were directed by strong, moral conscience. The White group (17\%) was composed of 15 individuals. They are the peacekeepers who liked to keep a low profile, independent and were motivated by other people's desire. Only eight people (9\%) belonged to the Red group or the power wielders who hungered for power and wanted to be productive. As shown in Fig. 1, the distribution of the subjects into different personalities was not equal. To come up with an accurate data considering the unequal distribution, calculating the simple average or mean was used to represent the performance of every personality grouping through scores obtained.

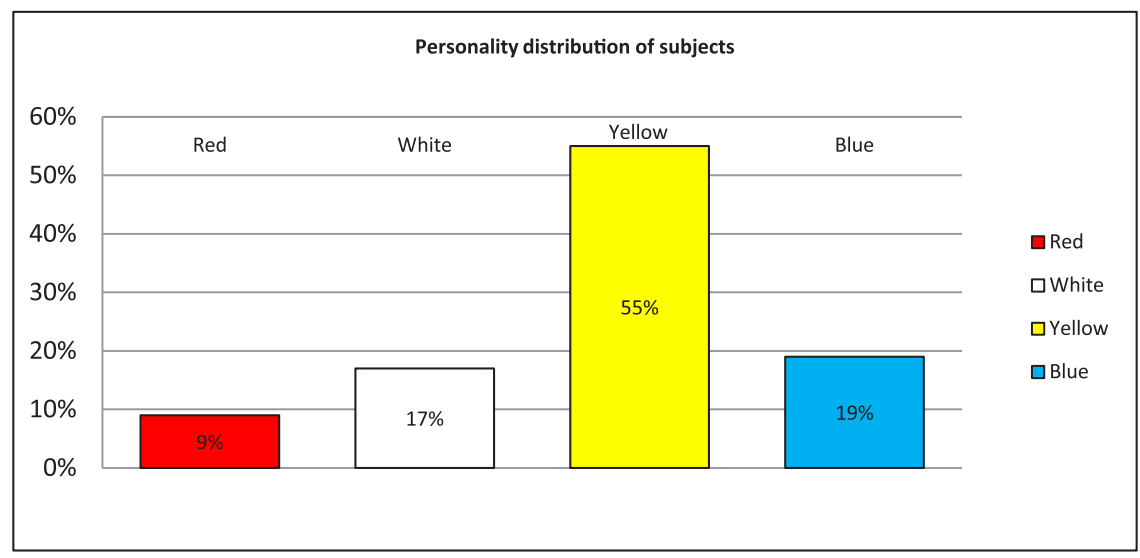

Fig. 1. Personality distribution of subjects 


\section{Performance of subjects in terms of average score according to personality in Pre-board 1 and Pre-board 2 (with and without interventions}

Fig. 2 shows the performance of subjects according to their personality groupings on Pre-board 1 and Pre-board 2. During preboard, results showed that the white group ranked first with an average score of 61.25 percent. Second in rank was the yellow group with an average score of 60.07 percent followed by the blue group with 58.32 percent. The Red group performed the lowest with an average score of 52.26 percent. During this instance, no psycho-emotional interventions were conducted before the examination. It is observed that there was no single personality grouping that reached the average passing rating of 75 percent as shown in the bluecolored bar graphs. The result, therefore, implies a low performance of the subjects on their Pre-board 1 examination. The result coincides with the findings of the study conducted by Furnham, Chamorro-Premuzic, \& McDougall (2002) about "Personality, cognitive ability, and beliefs about intelligence as predictors of academic performance" which shows that personality trait is significantly correlated with academic performance. It is further explained that the personality of the student is a strong predictor of his attitude, absenteeism, and behavior in his/her review classes.

The red-colored bar graphs as seen in Fig. 2, on the other hand, indicates the performance of the subjects according to their personality groupings in Pre-board 2. The result revealed that both the Red and Blue groups were able to reach more than the $75 \%$ ideal passing average. However, it was noted that there were observable decreases in the average scores of the White and Yellow Groups. It is important to note that before the subjects' Preboard 2 examination, the different personality groups underwent different activities as suited and indicated in their personality type. These psycho-emotional interventions were done simultaneously with the members of the Red group acting as the planners, organizers, and facilitators of every activity conducted by the remaining three personality groupings. A ceremonial stress debriefing activity was provided by the staff of Powerhouse 
Training and Review Center to all personality groups prior to the Preboard 2 examination. The findings coincided with the study of Gregor (2005) which emphasizes the utilization of different cognitive behavioral approaches combined with relaxation to effectively raise student's examination performance.

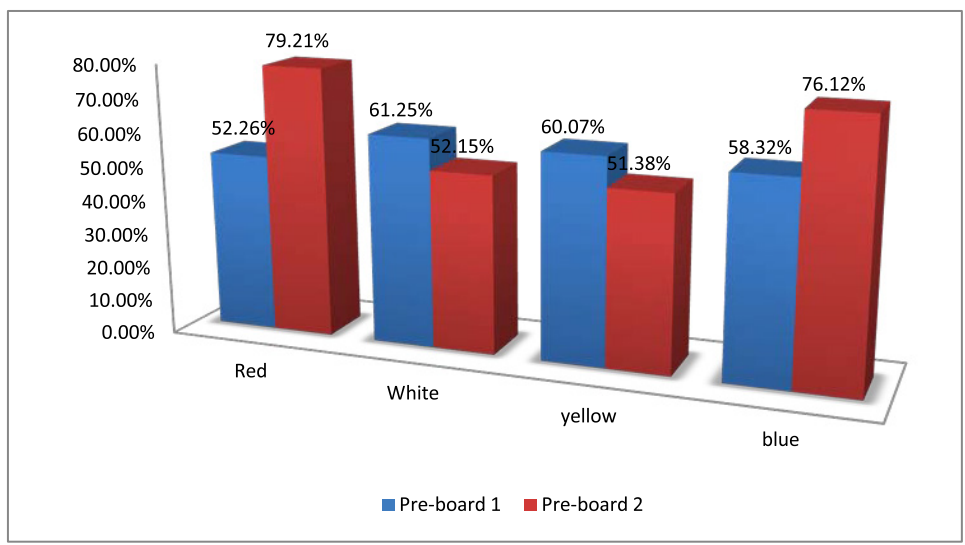

Fig. 2. Performance of subjects according to personality in Pre-board 1 and Pre-board 2

\section{Performance of the subjects in terms of passing rate according to personality in Pre-board 2 and NLE.}

The passing percentage for every personality type was also computed. The Simple percentage formula was utilized to determine the number of the members of the group who passed the examination both in Pre-board 2 and in the actual Nursing Licensure Examination. Data revealed that the blue group ranked first both in Pre-board 2 and in the NLE with a passing rate of 58.82 percent in Pre-board 2 and 76.47 percent in the NLE. The yellow group remained consistently low with a passing rate of 30.61 percent in Pre-board 2 and 38.78 percent in the NLE. The results were supported by the study of ChamorroPremuzic, \& Furnham (2003) which concluded that introverts and conscientiousness lead to higher academic achievement. The subjects received psycho-emotional interventions before the taking of the actual Nursing Licensure Examination with the aim of decreasing the anxiety felt by the NLE takers since it was also founded in the study of Chamorro that neuroticism or extreme anxiety and fear impairs academic performance. 


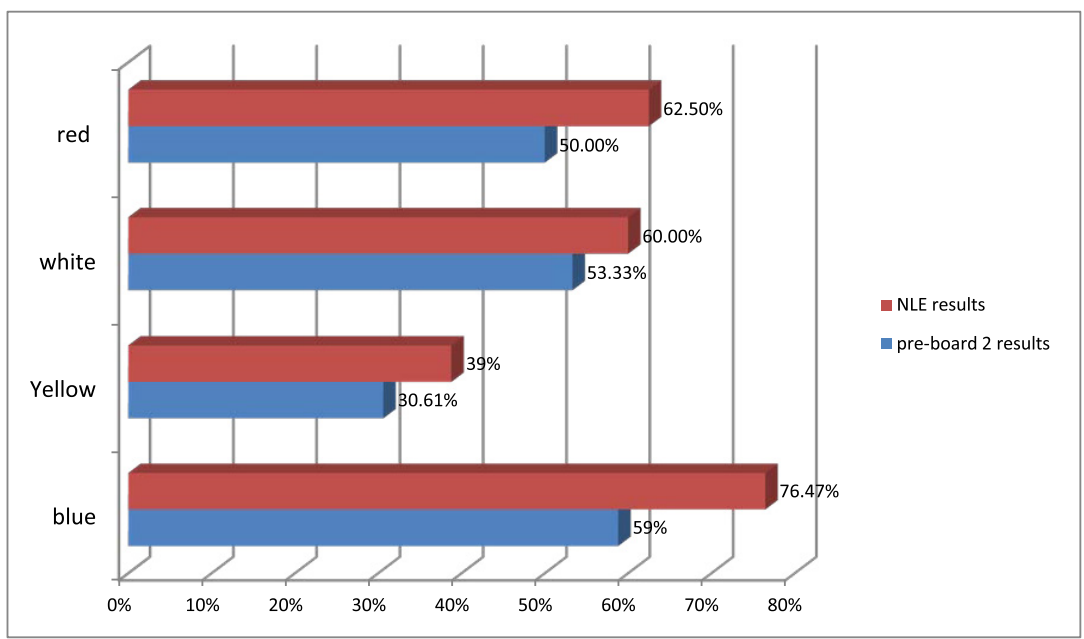

Fig. 3. Pre-board 2 and NLE performance in terms of passing rate according to personality group

\section{Performance in average scores between Pre-board 1 and Pre-board 2 according to personality (pre and post intervention comparison)}

The performance of the subjects in terms of average scores between Pre-board 1 and Pre-board 2 was compared. The result showed that the Red and Blue groups improved in their performances. The two groups were able to go beyond the passing average of 75 percent. To determine the significant relationship between the performance of the subjects based on their average score between Pre-board 1 and Pre-board 2 according to their personality, the data were subjected to chi-square test. The result revealed that a significant relationship did exist considering that the probability value is at 0.05 . It implied that the performances in both instances varied and that psycho-emotional interventions according to personality type were a contributing factor to this change.

Moreover, the performances of the subjects in terms of passing rates between Pre-board 2 and the subjects' NLE result were also looked into. It was revealed by the data that all personality groups improved in their performances. Consistently, the Blue group was still able to achieve a passing rate above average. The data were then subjected to Chi-square test, and it was found out that there was no significant relationship that exists considering that the probability value is at 0.90 which exceeded the critical value of 0.05 . 
It implied that the performance in Pre-board 2 and NLE, indicated that there were still changes but these outcomes were not due to the interventions as evidenced by the result of the Chi-square Test.

Table 1. Relationship of performance in average scores between

Pre-board 1 and Pre-board 2 according to personality

(pre-and-post intervention comparison)

\begin{tabular}{|c|c|c|c|c|c|c|c|}
\hline & $\begin{array}{c}\text { Psycho- } \\
\text { emotional } \\
\text { intervention }\end{array}$ & $\begin{array}{c}\text { Chi- } \\
\text { square } \\
\text { Computed } \\
\text { value }\end{array}$ & $\begin{array}{c}\text { Chi- } \\
\text { square } \\
\text { Refer- } \\
\text { ence } \\
\text { value }\end{array}$ & $\begin{array}{l}\text { Degrees of } \\
\text { Freedom }\end{array}$ & P-value & $\begin{array}{l}\text { Deci- } \\
\text { sion }\end{array}$ & $\begin{array}{c}\text { Interpre- } \\
\text { tation }\end{array}$ \\
\hline Pre-board 1 & $\begin{array}{c}\text { Without inter- } \\
\text { vention }\end{array}$ & \multirow{2}{*}{7.96} & \multirow{2}{*}{7.815} & \multirow{2}{*}{3} & \multirow{2}{*}{0.05} & \multirow{2}{*}{$\begin{array}{l}\text { Reject } \\
\text { hy- } \\
\text { pothe- } \\
\text { sis }\end{array}$} & \multirow{2}{*}{$\begin{array}{l}\text { Significant } \\
\text { relation- } \\
\text { ship }\end{array}$} \\
\hline Pre-board 2 & $\begin{array}{l}\text { With interven- } \\
\text { tion }\end{array}$ & & & & & & \\
\hline Pre-board 2 & $\begin{array}{c}\text { With interven- } \\
\text { tion }\end{array}$ & \multirow{2}{*}{0.289} & \multirow{2}{*}{7.815} & \multirow{2}{*}{3} & \multirow{2}{*}{0.05} & \multirow{2}{*}{$\begin{array}{l}\text { Accept } \\
\text { hy- } \\
\text { pothe- } \\
\text { sis }\end{array}$} & \multirow{2}{*}{$\begin{array}{l}\text { No signifi- } \\
\text { cant rela- } \\
\text { tionship }\end{array}$} \\
\hline NLE & $\begin{array}{l}\text { With interven- } \\
\text { tion }\end{array}$ & & & & & & \\
\hline
\end{tabular}

\section{CONCLUSION}

Based on the findings, the following conclusions were drawn

1. During Pre-board 1, the subjects did not receive any psychoemotional intervention, and results revealed a low performance in Pre-board 1 as none from the four personality group had attained a score that reached the passing percentage rating of $75 \%$.

2. The subjects underwent different types of psycho-emotional interventions before taking Pre-board 2. The performance in Preboard 2 was compared to the performance in Pre-board 1, and it was found out that two personality groups; the Red group and the Blue group; were able to have an improvement in their performance and that these two groups were already able to go beyond the passing of $75 \%$

3. As to the performance of the subjects between Pre-board 1 and Pre-board 2, no significant relationship was found according to personality. 
4. There was no significant relationship on the performance in terms of passing rates of the subjects between Pre-board 2 and NLE according to personality.

5.There was a significant relationship between personality-based psycho-emotional interventions and overall performance of the subjects according to their personality. The result has shown that there was a significant difference when the subjects received psycho-emotional interventions before taking an examination and compared to their performances when the subjects did not receive any psycho-emotional intervention at all.

\section{REFERENCES CITED}

Agarwal, S. K. (2014). Therapeutic Benefits of Laughter. History, 12(46), 19-23. Retrieved from http://goo.gl/sfTaJs, (accessed last 25 October 2015).

Alligood, M. R. (Ed.). (2013). Nursing theorists and their work. Elsevier Health Sciences. Elsevier Health Sciences, 2013. Retrieved from http:// goo.gl/j7wUHB, (accessed last 25 October 2015).

Bennett, M. P., Zeller, J. M., Rosenberg, L., \& McCann, J. (2003). The effect of mirthful laughter on stress and natural killer cell activity. Nursing Faculty Publications, 9. Retrieved from http://goo.gl/pZO8VQ, (accessed last 24 October 2015).

Brush, B. L., Sochalski, J., \& Berger, A. M. (2004). Imported care: Recruiting foreign nurses to US health care facilities. Health Affairs, 23(3), 78-87. Retrieved from http://goo.gl/VQ3EcK, (accessed last 25 October 2015).

Buerhaus, P. I., Donelan, K., Norman, L., \& Dittus, R. (2005). Nursing students' perceptions of a career in nursing and impact of a national campaign designed to attract people into the nursing profession. Journal of Professional Nursing, 21(2), 75-83. Retrieved from http://goo. gl/8QGGkX, (accessed last 26 October 2015).

Canadian Nurses Association. Planning for the Future: Nursing Human Resources Projections. Ottawa: Canadian Nurses Association; 2002. Retrieved from http://goo.gl/qKavc4, (accessed last 27 October 2015). 
Chan, Z. C., Chan, Y. T., Lui, C. W., Yu, H. Z., Law, Y. F., Cheung, K. L., ... \& Lam, C. T. (2015). Gender differences in the academic and clinical performances of undergraduate nursing students: A systematic review. Nurse education today, 34(3), 377-388. Retrieved from http:// goo.gl/z9zQeU, (accessed last 4 November 2015).

Chamorro-Premuzic, T., \& Furnham, A. (2003). Personality predicts academic performance: Evidence from two longitudinal university samples. Journal of Research in Personality, 37(4), 319-338. Retrieved from http://goo.gl/xgm0h, (accessed last 4 November 2015).

Coomber, B., \& Louise Barriball, K. (2007). Impact of job satisfaction components on intent to leave and turnover for hospital-based nurses: a review of the research literature. International journal of nursing studies, 44(2), 297-314. Retrieved from http://goo.gl/oh5P16, (accessed last 25 October 2015).

Duquette, A., Kérouac, S., Sandhu, B. K., Ducharme, F., \& Saulnier, P. (1995). Psychosocial determinants of burnout in geriatric nursing. International Journal of Nursing Studies, 32(5), 443-456. Retrieved from http://goo. gl/jkJOZ7, (accessed last 27 October 2015).

Freeman, S., Morgillo. (2005). Cognitive behavior therapy in nursing practice. Springer Publishing Company. Retrieved from http://goo.gl/ KYVPZI, (accessed last 26 October 2015).

Furnham, A., Chamorro-Premuzic, T., \& McDougall, F. (2002). Personality, cognitive ability, and beliefs about intelligence as predictors of academic performance. Learning and Individual Differences, 14(1), 4764. Retrieved from http://goo.gl/nNDhLp, (accessed last 4 November 2015).

Gay, G. (2010). Culturally responsive teaching: Theory, research, and practice. Teachers College Press. Retrieved from http://goo.gl/CjAfK6, (accessed last 26 October 2015).

Gregor, A. (2005). Examination Anxiety Live With It, Control It Or Make It Work For You? School Psychology International, 26(5), 617-635. Retrieved from http://goo.gl/1N7hL1, (accessed last 25 October 2015).

Hartman, T. (2000). Color Your Future: Using the Character Code to Enhance Your Life. Simon and Schuster. Retrieved from http://goo.gl/ 
nKKml3, (accessed last October 2015.)

Hartman, T. (2007). The color code: $A$ new way to see yourself, your relationships, and life. Simon and Schuster. Retrieved from http://goo. gl/jU69XW, (accessed last 26 October 2015).

Hartman, T. (2007). The People Code: It's All About Your Innate Motive. Simon and Schuster. Retrieved from http://goo.gl/vqkVGv, (accessed last 26 October 2015).

Horton, C., Polek, C., \& Hardie, T. L. (2012). The relationship between enhanced remediation and NCLEX success. Teaching and Learning in Nursing, 7(4), 146-151. Retrieved from http://goo.gl/O6O83F, (accessed last 26 October 2015).

Iken, L. H. (2007). US nurse labor market dynamics are key to global nurse sufficienc . Health Services Research, 42(3p2), 1299-1320. Retrieved from http://goo.gl/olhcKg, (accessed last 26 October 2015).

Jourdain, G., \& Chênevert, D. (2010). Job demands-resources, burnout and intention to leave the nursing profession: A questionnaire survey. International Journal of Nursing Studies, 47(6), 709-722. (Retrieved from http://goo.gl/4mppTG, (accessed last 24 October 2015).

Krausz, M., Koslowsky, M., Shalom, N., \& Elyakim, N. (1995). Predictors of intentions to leave the ward, the hospital, and the nursing profession: $A$ longitudinal study. Journal of Organizational Behavior, 16(3), 277-288. Retrieved form http://goo.gl/dp6twf, (accessed last 27 October 2015).

Lauchner, K. A., Newman, M., \& Britt, R. B. (2005). Predicting licensure success with a computerized comprehensive nursing exam: the HESI Exit Exam. Nurse educator, 30(3S), 4S-9S. Retrieved from http://goo. gl/eQY5du, (accessed last 26 October 2015).

Lehto, X. Y., Park, O., Fu, X., \& Lee, G. (2014). Student life stress and leisure participation. Annals of Leisure Research, (ahead-of-print), 1-18. Retrieved from http://goo.gl/8IPxIK, (accessed on 26 October 2015).

Lu, K. Y., Lin, P. L., Wu, C. M., Hsieh, Y. L., \& Chang, Y. Y. (2002). The relationships among turnover intentions, professional commitment, and job satisfaction of hospital nurses. Journal of Professional Nursing, 18(4), 214-219. Retrieved from http://goo.gl/iDhsLL, (accessed 
last 26 October 2015).

Mahony, D. L. (2000). Is laughter the best medicine or any medicine at all? Eye on Psi Chi, 4(3), 18-21. Retrieved from http://goo.gl/bvnf4h, (accessed last 25 October 2015).

Masselink, L. E., \& Jones, C. B. (2014). Immigration policy and internationally educated nurses in the United States: A brief history. Nursing outlook, 62(1), 39-45. Retrieved from http://goo.gl/0KbRpe, (accessed last 26 November 2015).

McAbee, R. (1991). Occupational stress and burnout in the nursing profession. A model for prevention. AAOHN journal: official journal of the American Association of Occupational Health Nurses, 39(12), 568575. Retrieved from http://goo.gl/sBYLE8, (accessed last 27 October 2015).

Mischel, W., \& Shoda, Y. (1995). A cognitive-affective system theory of personality: reconceptualizing situations, dispositions, dynamics, and invariance in personality structure. Psychological review, 102(2), 246. Retrieved from http://goo.gl/m6FzUS, (accessed last 27 October 2015).

Moore, L. L., Gardner, K. A., \& Guenthner, J. F. (2008). Potential Use of Hartman's Color Code Personality Profile to Enhance Classroom Group Projects. NACTA Journal. Retrieved from http://goo.gl/6tfhhy, (accessed last 27 October 2015).

Nogueras, D. J. (2005). Occupational commitment, education, and experience as a predictor of intent to leave the nursing profession. Nursing economic\$, 24(2), 86-93. Retrieved from http://goo. gl/LnHwjo, (accessed last 25 October 2015).

Parker, M. E., \& Smith, M. C. (2010). Nursing theories \& nursing practice. Retrieved from http://goo.gl/MtG2M9_(accessed last 25 October 2015).

Peale, N. V. (2012). The power of positive thinking. Random House. Retrieved from http://goo.gl/Hmrx9A, (accessed last 24 October 2015).

Penson, R. T., Partridge, R. A., Rudd, P., Seiden, M. V., Nelson, J. E., Chabner, B. A., \& Lynch, T. J. (2005). Laughter: the best medicine? The Oncologist, 10(8), 651-660. Retrieved from http://goo.gl/V9s2uL, (accessed last 25 October 2015). 
Pervin, L. A., \& John, O. P. (Eds.). (1999). Handbook of personality: Theory and research. Elsevier. Retrieved from http://goo.gl/Kpqkzw, (accessed last 26 October 2015).

Phillips, K. D., Blue, C. L., Brubaker, K. M., Fine, J. M. B., Kirsch, M. J., Papazian, K. R., ... \& Sobiech, M. A. (1998). Adaptation model. Nursing theorists and their work, 243-266. Retrieved from http://goo.gl/Z9cjGC, (accessed on 25 October 2015).

Sand-Jecklin, K. E., \& Schaffer, A. J. (2006). Nursing students' perceptions of their chosen profession. Nursing Education Perspectives, 27(3), 130135. Retrieved from http://goo.gl/qRVd8n, (accessed last 27 October 2015).

Segerstrom, Suzanne C., and Gregory E. Miller. (2004). "Psychological stress and the human immune system: a meta-analytic study of 30 years of inquiry." Psychological bulletin 130.4: 601. Retrieved from http://goo.gl/FSE7f, (accessed last 26 October 2015).

Selye, H. (1950). Stress and the general adaptation syndrome. British medical journal, 1(4667), 1383. Retrieved from http://goo.gl/ CCA9Ld, (accessed last 23 October 2015).

Selye, H. (1956). The stress of life. Retrieved from http://goo.gl/zJtc0Z, (accessed last 26 October2015).

Sharma, H. K. (2011). Sage open. Stress and Relaxation in Relation to Personality, 4, 4-10. Retrieved from http://goo.gl/88Kg3H, (accessed last 26 October 2015).

Shields, M. A., \& Price, S. W. (2002). Racial harassment, job satisfaction and intentions to quit: evidence from the British nursing profession. Economica, 69(274), 295-326. Retrieved from http://goo.gl/ DsFzlw, (accessed on 27 October 2015).

Skrable, L., \& Fitzsimons, V. (2014). Simulation in associate degree nursing education: A literature review. Teaching and Learning in Nursing, 9(3), 120-125. Retrieved from http://goo.gl/ccMiSY, (accessed last 4 November 2015). 
Tackenberg, P., \& Müller, B. (2003). Working conditions and intent to leave the profession among nursing staff in Europe. H. M. Hasselhorn (Ed.). Stockholm: National Institute for Working Life. Retrieved from http:// goo.gl/pAoOVQ. (accessed on 15 October 2015).

Taylor, S. E., Klein, L. C., Lewis, B. P., Gruenewald, T. L., Gurung, R. A., \& Updegraff, J. A. (2000). Biobehavioral responses to stress in females: tend-and-befriend, not fight-or-fligh Psychological review, 107(3), 411. Retrieved from http://goo.gl/rgPrrX, (accessed last 26 October 2015).

Weissmann, Gerald. (2007). "The experimental pathology of stress: Hans Selye to Paris Hilton." The FASEB Journal 21.11: 2635-2638. Retrieved from http://goo.gl/eWVw2G, (accessed on 26 October 2015). 